\title{
A simple dryland beef production system
}

\author{
A.M: NICOL \\ Department of Animal Science, Lincoln University
}

\begin{abstract}
At Lincoln University, a small (3.7 ha) beef unit operates annually with the objective of closely fitting seasonal pasture growth rate to cattle feed demand on Canterbury dryland pasture with no requirement for making or feeding conserved feed. Inputs to this dryland pasture beef production system are kept low. Cattle are not purchased in autumn until the results of a feed budget show that pasture mass plus expected winter pasture growth will meet target animal winter intake. In some years not all cattle are bought at the same time, but the unit is fully stocked (around 6 cattle/ha) by the end of July. Cattle are sold for slaughter progressively from December through February as pasture production ceases to meet animal demands. Grazing methods typically vary from autumn-winter rotations of up to 100 days with weekly block grazing, to 6-paddock rotations of 28-34 days in spring and 2-paddock, 30-day spelling intervals later in the grazing season.

- The unit-consistently produces-each--year a carcass weight gain of $500 \mathrm{~kg} / \mathrm{ha}$ with gross margins of around $\$ 400-600 /$ ha representing a utilisation of $100 \mathrm{GJ} \mathrm{ME} / \mathrm{ha}$. This performance is consistent with that of other intensive beef production systems.
\end{abstract}

Keywords beef production, dryland, seasonal pasture production

\section{Introduction}

Cätțle represent a small proportion (3\%) of the stock units carried on South Island intensive sheep farms (NZMWBES 1989), particularly those in the drier eastern regions of the island, possibly reflecting unreliable early autumn pasture growth and dry summers plus the absence of beef systems which can accommodate these climatic variables. For beef cattle numbers to expand relative to other livestock, beef finishing systems need to be designed for such farming environments. Beef finishing systems can be flexible in their demand for feed due to the availability of, and demand for, cattle over most of the year, at least in numbers to meet the requirements of individual farmers, and therefore systems to suit the drier more variable climate of Canterbury should be feasible. Recently, much emphasis has been placed on bull beef production systems (Everitt \& Ward 1974; McRae 1988), but only $25 \%$ of cattle slaughtered (exclusive of cows and bobby calves) are bulls, and more information is needed on dryland systems producing prime beef.

As part of its teaching programme, Lincoln University runs a small beef finishing unit which copes with the vagaries of Canterbury dryland pasture production and produces prime beef for the local and export markets. The main aim of the unit is to operate an annual beef finishing system which closely fits cattle feed demand to seasonal pasture production with no requirement for making or feeding conserved pasture - a low cost system. The unit provides students and staff the opportunity to plan and operate a self-contained unit in which inputs and outputs can be monitored. The Unit must also contribute income to the University Farm, although maximum profit is not the prime objective. This paper describes the unit, details its productivity over-.-years-and-compares-its-output-ta-tli\%t of other New Zealand grassland beef production systems.

\section{The Lincoln University Beef Teaching Unit (LUBTU)}

\section{Physical features}

The LUBTU consists of 3.7 effective hectares of an aged permanent pasture containing perennial ryegrass, cocksfoot, white clover, barley grass and yarrow on approximately equal proportions of Templeton silt loam and Wakanui silt loam sheltered only to the east. The area is permanently divided into two equi-sized paddocks, but more paddocks are possible by temporary electric subdivision. Stock water is supplied, but the area is not irrigated.

Policy

There is no fixed beef finishing system, but the unit must function within a number of constraints, e.g.

(1) a close match of cattle feed demand to pasture in situ supply.

(2) 12-month production cycle; therefore there can be no carry-over of cattle from one production cycle to the next. 
(3) cattle sold from the unit must be slaughtered (gives quantitative data on output), precluding a "store to store" system.

(4) minimum labour input and cost, e.g. infrequent grazing shifts and no hay-silage making or feeding out. The absence of supplementary feeding is supported by the work of Taylor \& Scales (1985).

(5) acceptable standards of pasture and animal welfare must be observed.

\section{System design}

The basic premise in designing the system is that a peak spring (November) pasture consumption (production) of $50 \mathrm{~kg}$ dry matter (DM)/ha/day will sustain $2000 \mathrm{~kg}$ liveweight per ha (e.g. 4 animals of $500 \mathrm{~kg}$ liveweight, $5 \times 400 \mathrm{~kg}, 6 \times 330 \mathrm{~kg}$ ), all animals gaining $1.2 \mathrm{~kg} /$ head/day over this period.

The remainina decisions involve:

(i) a balanced, progressive, build-up of the effective animal demand to this peak. Animal demand is a function of the number of animals, their sex, stage of development, liveweight and liveweight gain, all of which can be varied through the cattle bought and the target performance levels set.

(ii) ensuring there are cattle suitable for slaughter to reduce the demand as pasture production decreases after November.

\section{Progressive stocking}

Depending on the early (March-April) autumn growth, one of two re-stocking options is used in the autumn-winter. In years of poor autumn pasture production, the decision to buy cattle is usually withheld until pasture cover is sufficient to sustain the full complement of cattle until the end of August. Figure 1 shows the result of this calculation in the autumn of 1989 (100 mm rain in Feb-April). A purchase date of early July was indicated, because by this date the total pasture available would meet the cattle demand until the end of winter (31 August). In years of good early autumn growth, a proportion of the cattle (usually about 50\%) are bought in April with the remainder purchased late in winter. This option was taken in 1987 (276 mm rain in Feb-April).

\section{Summer destocking}

Cattle are sold progressively over summer when feed demand exceeds pasture growth to prevent mean pasture mass declining to below about $1400 \mathrm{~kg}$ $\mathrm{DM} / \mathrm{ha}$. The necessity of having cattle available for slaughter in appropriate carcass weight and fatness classes from November dictates the type of cattle used in the system. The cattle used are either 6-15 month heifers or older (18-30 months) steers of which no more than $50 \%$ of the genotype is late maturing. Younger cattle are suitable for only the early autumn purchase option because of the need to grow them during winter to each satisfactory slaughter liveweight by Dee-Jan, but older cattle suit buying later in the winter.

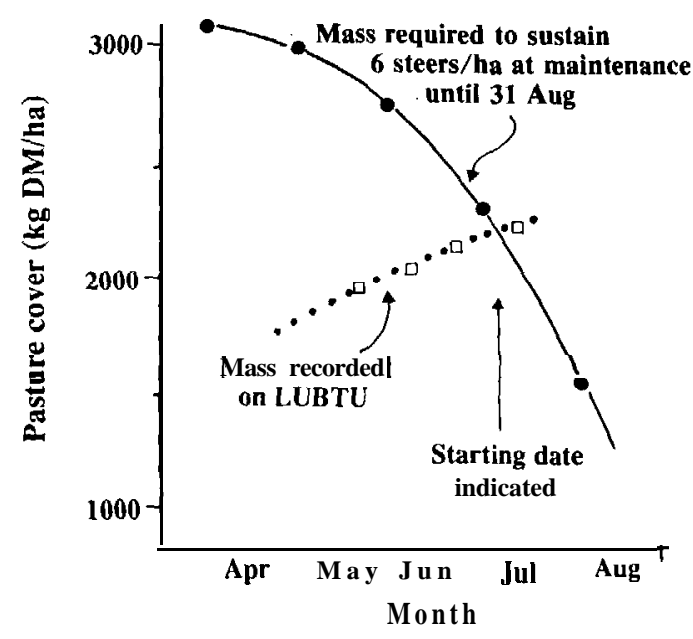

Fire 1 The cumulative autumn pasture mass and pasture demand of cattle on the LUBTU for autumn-winter 1989.

An example of the targets set for growth rate and carcass weight and grade with those achieved is illustrated for 1987-88 (Figure 2).

\section{Grazing methods}

Rotational grazing is practised all year round with autumn winter rotations of up to 100 days with weekly block grazing; 6-paddock rotations of 28-34 days in spring; and a more lax 2-paddock, 30- to 35-day spelling interval later in the grazing season. Pre-grazing pasture mass is kept above $2000 \mathrm{~kg}$ $\mathrm{DM} /$ ha and cattle intake will be restricted if necessary in early spring by a slow rotation until this pre-grazing pasture mass is generated. Post-grazing pasture mass ranges from $600-700 \mathrm{~kg} \mathrm{DM} / \mathrm{ha}$ in late winter with older cattle at maintenance, to $1600-1700$ in late spring.

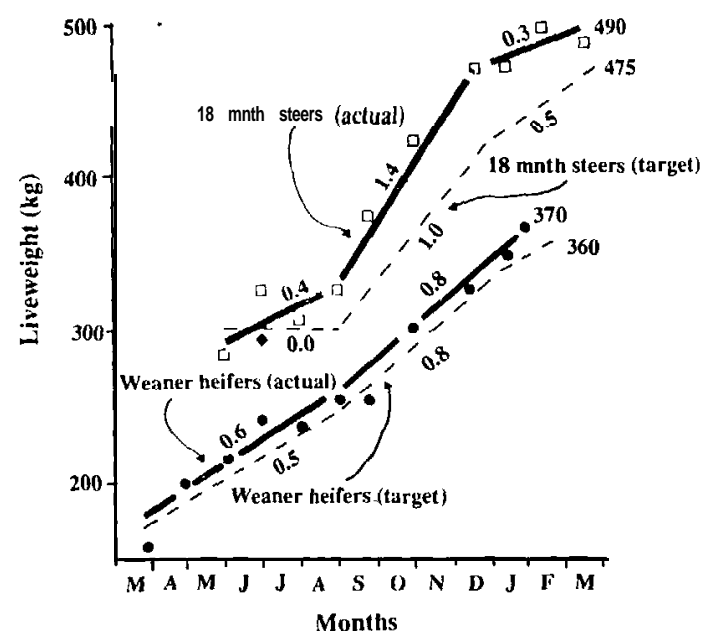

Figure 2 The target and actual liveweight profile of cattle on the LUBTU in 1987-88. 
Table 1 Physical and financial productivity of the Lincoln University Beef Teaching Unit for 1986-87, 1987-88 and 1989-90.

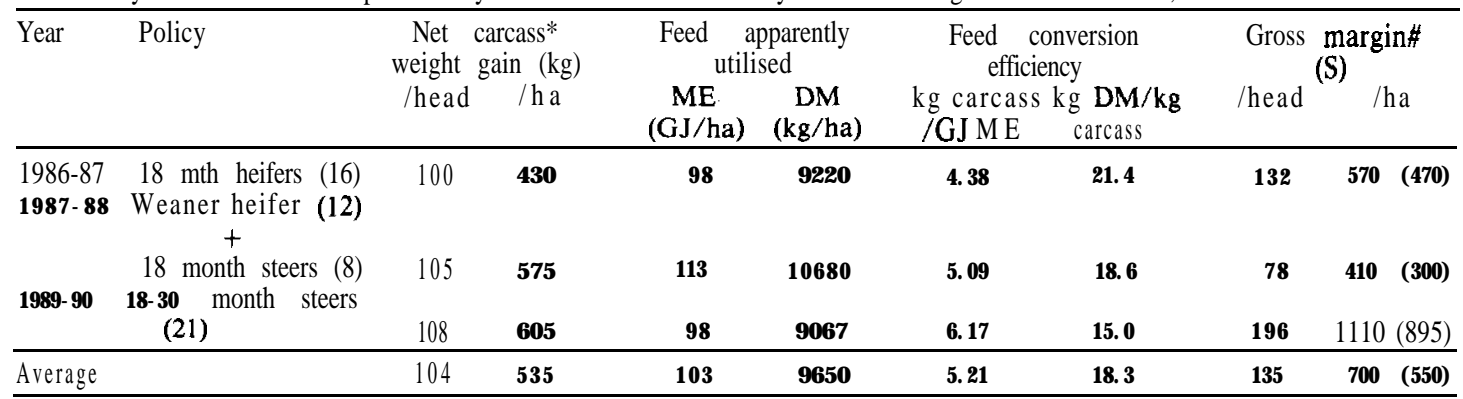

Notes:

* Final carcass weight less estimate of carcass weight at purchase from liveweight (dressing out $\% 50 \%$ ).

$\dagger$ Calculated from the ME requirement/month based on mean liveweight and liveweight gain and ME requirement for cattle (Geenty \& Rattray, 1980). ME concentration of pasture consumed was taken as ranging from a high of 11.5 $\mathrm{MJME} / \mathrm{kg}$ DM in spring to low of 9.0 in late summer.

\#Gross margin $=$ Sale price (net of charges, and transport) less purchase price plus transport plus animal health. Value in brackets net of interest charged at $18 \%$ per annum.

\section{Productivity}

The unit has produced annually an average of $535 \mathrm{~kg}$ net carcass gain/ha and returned the Research Farm a gross margin (net of interest) of $\$ 500 /$ ha from an apparent DM consumption of $9650 \mathrm{~kg} \mathrm{DM} / \mathrm{ha}$ (Table $1)$. Of note is the consistency of the physical performance of the Unit and instability between years of the financial return. The consistent physical performance is a reflection of relatively little variation between years in the seasonal pattern of DM apparently consumed (Figure 3) and a fairly constant proportion of ME devoted to maintenance and growth as suggested by the relative consistent feed conversion efficiency (FCE) ratio.

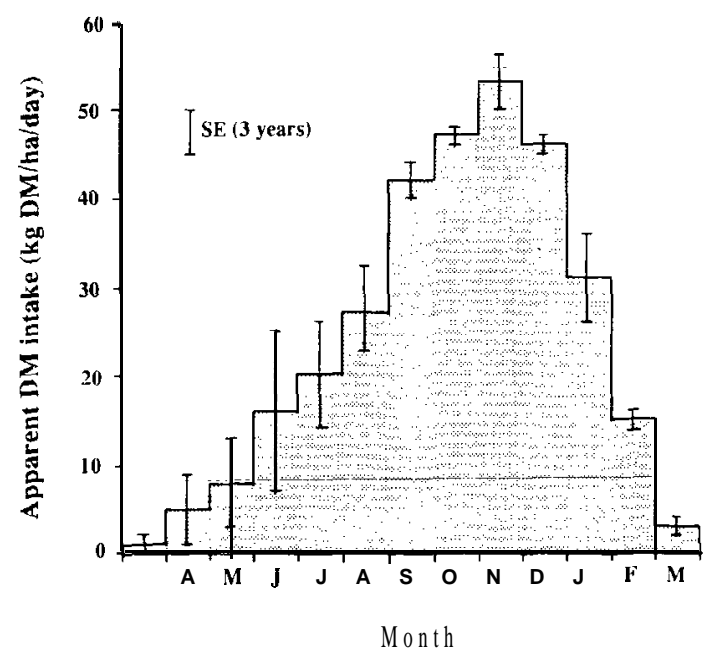

Figure 3 The monthly pattern of apparent pasture consumption on the LUBTU (mean \pm SE for 3 years).

Note: Apparent pasture consumption was calculated by applying the recommended feed requirements of beef cattle to the appropriate liveweight and liveweight gain of the cattle present on the Unit each month.
The widely fluctuating financial returns to the unit are chiefly a function of the extent purchase price/kg exceeds the eventual sale price $/ \mathrm{kg} \rightarrow$ the negative margin (Table 2). For example, the 1987-88 cattle had to gain $63 \mathrm{~kg}$ carcass weight before their carcass value was equal to their purchase price, while in 1989-90 the negative margin was equivalent to only $30 \mathrm{~kg}$ carcass weight. Other systems may be able to reduce these fluctuations in financial returns but at some cost to the system.

\section{Comparison with other systems}

The performance of our Unit is similar to that of others which had utilised beef weaner steers and heifers in an annual system (Joyce 1970; Taylor \& Scales 1985) and the slightly lower carcass gain/ha of the LUBTU reflects the lower pasture production -under-dryland-rather-than-a-lower-pasture-conversion efficiency (Table 3). The output per ha of some dairy bull beef systems is higher (Everitt \& Ward 1974; Brougham et al. 1975), partly because of the low liveweight $(80-100 \mathrm{~kg}$ vs $180-200 \mathrm{~kg}$ ) of the animals introduced to the system and the light carcass weights produced at a high stocking rate (Brougham et al. 1975). Where bulls are carried at lower stocking rates to higher individual weights (McRae 1988), output

Table 2 Input and output prices of cattle on the Lincoln University Beef Teaching Unit over three years.

\begin{tabular}{|c|c|c|c|}
\hline & $1986-87$ & $1987-88$ & $1989-90$ \\
\hline $\begin{array}{l}\text { Purchase price } \\
\$ / \mathrm{kg}\end{array}$ & 1.87 & 2.70 & 3.22 \\
\hline $\begin{array}{l}\text { Estimated carcass weight } \\
(\mathrm{kg}) \text { at purchase }\end{array}$ & 140 & 103 & 135 \\
\hline $\begin{array}{l}\text { Sale price } \\
(\$ / \mathrm{kg} \text { actual carcass wt. })\end{array}$ & 1.71 & 1.67 & 2. 63 \\
\hline $\begin{array}{l}\text { Actual carcass weight }(\mathrm{kg}) \\
\text { at slaughter } \\
\text { Differential (purchase - sa }\end{array}$ & 240 & 208 & 242 \\
\hline $\begin{array}{l}\text { Differential (purchase }- \text { sale } \\
\text { s/kg } \\
\% 0 \text { sale price }\end{array}$ & $\begin{array}{l}\text { 0.16 } \\
9.3\end{array}$ & $\begin{array}{r}1.03 \\
62.0\end{array}$ & $\begin{array}{c}0.59 \\
22\end{array}$ \\
\hline
\end{tabular}


Table 3 Comparison of the physical output of Lincoln University Beef Teaching Unit with other self-contained beef units.

\begin{tabular}{|c|c|c|c|c|c|}
\hline System & District & $\begin{array}{c}\text { Average } \\
\text { net carcass } \\
\text { weight gain/ha } \\
(\mathrm{kg})\end{array}$ & $\begin{array}{c}\text { Average } \\
\text { carcass } \\
\text { weight } \\
(\mathrm{kg}) \\
\end{array}$ & $\begin{array}{c}\text { Pasture conversion } \\
\text { efficiency } \\
\text { (kg DM } / \mathrm{kg} \text { carcass } \\
\text { weight) }\end{array}$ & Source \\
\hline $\begin{array}{l}\text { Beef } \\
\text { (various } \begin{array}{c}\text { steers/heifers } \\
\text { ages) }\end{array}\end{array}$ & $\begin{array}{l}\text { Canterbury } \\
\text { (dryland) }\end{array}$ & 535 & 230 & 18.3 & This paper \\
\hline $\begin{array}{l}\text { Weaner steer heifers } \\
\text { to } 20 \text { months }\end{array}$ & $\begin{array}{l}\text { Canterbury } \\
\text { (irrigation) }\end{array}$ & 560 & 195 & 22.0 & Taylor \& Scales 1985 \\
\hline Beef weaners & $\begin{array}{l}\text { Canterbury } \\
\text { (irrigation) }\end{array}$ & 585 & 190 & 16.0 & Taylor 1975 \\
\hline Beef weaners & Waikato (lucerne) & 445 & 165 & & Marsh \& Brunswick 1977 \\
\hline Beef weaners & Waikato & 655 & 200 & 18.2 & Joyce 1970 \\
\hline 20-month bulls & Manawatu & 620 & 222 & & McRae 1988 \\
\hline 20-month bulls & Waikato & 800 & ? & 17.5 & Everitt \& Ward 1974 \\
\hline 15-month bulls & Manawatu & 1000 & 165 & 11.8 & Brougham et at. 1975 \\
\hline
\end{tabular}

and pasture conversion efficiency per ha may not be as high.

Most beef cattle are not farmed in self-contained systems, but integrated in sheep farms (NZDS 1989). To compare beef production in the LUBTU with that on mixed sheep and beef farms, the stocking rate of our unit has been taken as $15 \mathrm{su} / \mathrm{ha}$, e.g. $9650 \mathrm{~kg}$ $\mathrm{DM}$, the mean annual apparently consumed per ha on our unit divided by $650 \mathrm{~kg} \mathrm{DM}$, the annual DM requirement of a ewe plus her lamb to slaughter. The LUBTU produces a similar output of beef/su, but a higher beef production per effective area in cattle than the other major beef finishing farm classes (Table 4). The small size of the LUBTU perhaps makes a higher stocking rate easier to manage. On the other hand, there may be less emphasis on finishing cattle on a mixed sheep-beef farm to graze to low pasture masses over winter (the ewe flock is used for this purpose). Furthermore, cattle may not be slaughtered as early in the season (lambs are killed first) which could lead to a relatively higher beef output/su on mixed farms than on all-beef units.

\section{Conclusions}

The primary role of the Lincoln University Beef Teaching Unit is as a teaching resource. However, it does demonstrate that through flexibility in time, number and type of cattle purchased, and by ensuring there are cattle suitable to kill from late spring through early summer, a low-input beef finishing system can operate satisfactorily under the variable Canterbury climate. The productivity of the unit is similar to that of other beef units in more predictable environments.

\section{REFERENCES}

Brougham, R.W ; Causley, D.C.; Madgwick, L.E. 1975. Pasture management systems and animal production. Proceedings of the Ruakura Farmers' Conference 1975: $65-69$.

Everitt, G.C.; Ward, J.D.B. 1974. Bull beef production. Proceedings of the Ruakura Farmers Conference 1974: 81-95.

Geenty, K.G.; Rattray, P.V. 1980. The energy requirements of grazing sheep and cattle in 'Livestock Feeding on Pasture' A.M. Nicol (ed.). 0 ccasional Publication No, 10. NZ Society of Animal Production.

Joyce, J.P. 1970. Intensive beef and sheep production. Proceedings of the NZ Grassland Association 32: 168-180.

Marsh, R.; Brunswick, L.F. 1977. Beef production from lucerne and lucerne/prairie grass swards on the pumice soils of the Taupo region. Proceedings of the NZ Grassland Association 39: 79-85.

McRae, A.F. 1988. Bull beef production. The Tuapaka experience. Proceedings of the Grassland Association 49: $41-45$.

NZDS 1988. Agricultural Statistics 1988, NZ Department of Statistics, Wellington.

NZMWBES 1989. NZ sheep and beef cattle survey 1987-88. Production and financial analysis. Publication No. 2006, NZ Meat and Wool Boards Economic Service. Wellington.

Taylor, A.G. 1975. Effect of stocking rate on pasture production under irrigation and growth of young cattle. Proceedinns of the NZ Grassland Association 37: 104-113.

Tavlor. A.G.: Scales. G.H. 1985. Effect of level of hay conservation on beef production. NZ journal of experimental agriculture $13: 155-161$.

Table 4 Comparison of the physical output of the Lincoln University Beef Teaching Unit with beef production from other farm classes.

\begin{tabular}{|c|c|c|c|c|}
\hline Measure & LUBTU & Intensive finishing* $^{\text {SI }}$ & $\begin{array}{l}\text { Farm } \\
\text { NI } \\
\text { Intensive }\end{array}$ & $\begin{array}{l}\text { SI } \\
\text { Breeding and } \\
\text { finishina }\end{array}$ \\
\hline $\begin{array}{l}\text { \% SU as beef cattle } \\
\mathrm{kg} \text { beef/SU in cattle } \\
\mathrm{kg} \text { beef/effective ha in cattle }\end{array}$ & $\begin{array}{l}100 \\
5::\end{array}$ & $\begin{array}{r}3.0 \\
30 \\
380\end{array}$ & $\begin{array}{r}24.0 \\
290\end{array}$ & $\begin{array}{l}10.5 \\
20 \\
185 \\
\end{array}$ \\
\hline
\end{tabular}

*Source: NZMWBES 1989 